\title{
Działalność Oddziału Katowickiego Polskiego Towarzystwa Dermatologicznego w kadencji od 4.06.2009 do 3 I.0I.20I 4 roku
}

Przegl Dermatol 20I4, I0I, 24I-242

W styczniu 2014 roku upłynęła kadencja władz Oddziału Śląskiego PTD. Od czerwca 2009 roku w skład zarządu Oddziału wchodzili: przewodnicząca - prof. zw. dr hab. med. Ligia Brzezińska-Wcisło, zastępca przewodniczącej - dr med. Ewa Krauze, sekretarz - dr med. Iwona Rogala-Poborska, skarbnik - dr med. Bożena Suwała-Jurczyk, członkowie - dr med. Mariola Wyględowska-Kania, lek. Dorota Sobel, lek. Jadwiga Bergier-Miedzińska. Komisję rewizyjną tworzyli: przewodnicząca - dr med. Barbara Filipowska, członkowie - dr med. Danuta Rasiewicz, lek. Barbara Seredyńska.

Na początku kadencji liczba członków Oddziału wynosiła 335 osób. W poczet nowych członków przyjęto 29 osób, z powodu niepłacenia składek skreślono 14 osób. Z naszego grona odeszli: Ewa Sobolta, Barbara Kalinka-Woźniak, Władysław Powroźny, Irena Rzewuska, Teresa Kochanowicz-Małysz, Halina Glik-Szulc, Magdalena Kwiecińska, Ewa Krauze - nasza wieloletnia koleżanka z Kliniki Dermatologii w Katowicach, Irena Rzepecka, Halina Jerzykowska, Hanna Marszałek. Na koniec kadencji Oddział liczył 339 osób.

Zarząd Oddziału Katowickiego PTD zbierał się 12 razy. W listopadzie 2010 roku odznaczono i wręczono dyplomy uznania za wybitne zasługi w działalności Oddziału Śląskiego PTD następującym lekarzom: lek. med. Ludmile Niewymierzyckiej-Kłysik, lek. med. Helenie Chruściel-Górka, dr med. Grażynie Luderze-Zimoch oraz dr. med. Arturowi Wentkowskiemu. Zorganizowano 39 posiedzeń naukowo-szkoleniowych. Ciężar organizacji posiedzeń wzięła na siebie Klinika Dermatologii w Katowicach - 24 posiedzenia, a oddział kliniczny w Zabrzu zorganizował 5 posiedzeń. Część zebrań odbyła się $\mathrm{w}$ terenowych oddziałach dermatologicznych: oddziały dziecięce w Katowicach i Cieszynie po 2, natomiast w Bytomiu, Tychach, Chorzowie, Rybniku i Zawierciu po 1. Na posiedzeniach wygłoszono 51 wykładów i demonstrowano 259 przypadków chorobowych, które obejmowały rzadkie i trudne diagnostycznie schorzenia dermatologiczne. Z grona profesorskiego naszego terenu prof. zw. dr hab. med. Ligia Brzezińska-Wcisło miała 8 bardzo interesujących wykładów, jak zwykle okraszonych przepiękną ikonografią, prof. dr hab. med. Jerzy
Jarząb przedstawił 1 wykład. Referaty naukowe wygłaszali zaproszeni wybitni polscy dermatolodzy reprezentujący najwyższe autorytety w kraju. Ponadto wspólnie z Oddziałem Katowickim Polskiego Towarzystwa Farmaceutycznego od 2010 roku organizowano coroczne, cieszące się ogromnym powodzeniem konferencje naukowo-szkoleniowe poświęcone leczeniu chorób dermatologicznych oraz zasadom wypisywania leków recepturowych i nowym podłożom. Lekarze będący w trakcie przygotowywania się do specjalizacji z dermatologii i wenerologii wygłosili 63 referaty wymagane do realizacji specjalizacji.

Członkowie oddziału brali czynny lub bierny udział w licznych zjazdach, sympozjach i konferencjach polskich oraz zagranicznych. Ogółem prezentowano 130 prac (w tym na zjazdach polskich 101, a na zjazdach zagranicznych 29). Publikacje polskie 117: Klinika Dermatologii w Katowicach - 94 (w tym 1 książka i 1 rozdział), Oddział Kliniczny w Zabrzu 21, inne ośrodki - 2 publikacje. Publikacje zagraniczne - 40: Klinika Dermatologii w Katowicach - 17, Oddział Kliniczny w Zabrzu - 23. Dwie osoby uzyskały stypendia zagraniczne - dr med. Agata Filipowska-Grońska (Rzym, 10-14.11.2010) i dr med. Małgorzata Latusek (Miami Beach, 1-5.03.2013).

Katedra i Klinika Dermatologii Śląskiego Uniwersytetu Medycznego zorganizowała XXII Sympozjum Sekcji Alergologicznej Polskiego Towarzystwa Dermatologicznego "Choroby alergiczne skóry - problem XXI wieku” w Katowicach w dniach 3-5.12.2009 roku.

Przewodniczącej prof. dr hab. med. Ligii Brzezińskiej-Wcisło nadano tytuł profesora zwyczajnego. Ponadto jest ona członkiem prezydium Zarządu Głównego PTD od września 2008 roku (21.09.2012 roku została wybrana na drugą kadencję).

W lipcu 2012 roku prof. dr hab. med. Jerzy Jarząb uzyskał tytuł naukowy profesora nauk medycznych nadany przez Prezydenta Rzeczypospolitej Polskiej.

Stopień naukowy doktora habilitowanego w dziedzinie nauk medycznych uzyskały 2 koleżanki z Kliniki Dermatologii w Katowicach: Anna Lis-Święty (2012) i Beata Bergler-Czop (2013). Ponadto 8 osób uzyskało stopień doktora nauk medycznych, 5 osób ma otwarty przewód doktorski. Tytuł specjalisty w dziedzinie dermatologii i wenerologii uzyskało 17 lekarzy. 
Doktor hab. med. Anna Lis-Święty jest sekretarzem Głównej Komisji Rewizyjnej PTD.

Należy z ogromną przyjemnością zaznaczyć, że nasza przewodnicząca prof. zw. dr hab. med. Ligia Brzezińska-Wcisło wykazała się jak zwykle, pomimo wielu obowiązków, nadzwyczajną aktywnością i uzyskała 4 zespołowe nagrody Rektora SUM w Katowicach w zakresie działalności naukowej: 2010 II stopnia, 2012 - 2 razy III stopnia, 2013 - II stopnia, w 2010 roku medal „Academia Medica Wratislaviensis Polonia” w uznaniu zasług dla rozwoju działalności uczelni przyznany przez Senat Akademii Medycznej im. Piastów Śląskich we Wrocławiu, w 2012 roku tytuł Partnera Polskiej Akademii Dermatologii i Wenerologii - wyróżnienie w formie statuetki, a w 2013 roku Medal Śląskiego Uniwersytetu Medycznego w Katowicach przyznany przez JM Rektora SUM za wybitne osiągnięcia i zasługi w pracy naukowej i dydaktycznej.

Doktor hab. med. Anna Lis-Święty otrzymała 3 zespołowe nagrody Rektora Śląskiego Uniwersytetu Medycznego w Katowicach w zakresie działalności naukowej: 2010 - II stopnia, 2012 - I stopnia, 2013 II stopnia.

Doktor hab. med. Beata Bergler-Czop otrzymała 3 zespołowe nagrody Rektora Śląskiego Uniwersytetu Medycznego w Katowicach w zakresie działalności naukowej: 2010 - II stopnia, 2012 - III stopnia, 2013 - II stopnia, a także nagrodę II stopnia w zakresie działalności organizacyjnej w roku akademickim 2012/2013.

Zespołową nagrodę I stopnia Rektora Śląskiego Uniwersytetu Medycznego w Katowicach w zakresie działalności naukowej w 2013 roku otrzymali: prof. dr hab. med. Jerzy Jarząb, dr med. Barbara Filipowska i dr med. Agata Filipowska-Grońska.
Zespołową nagrodę II stopnia Rektora Śląskiego Uniwersytetu Medycznego w Katowicach w zakresie działalności naukowej otrzymały: dr med. Iwona Rogala-Poborska (2010), dr med. Magdalena Kolanko (2010), dr med. Dorota Trzmiel (2013), dr med. Mariola Wyględowska-Kania - III stopnia (2012) oraz indywidualną dydaktyczną III stopnia (2009), dr med. Elżbieta Meszyńska (2013) oraz II nagrodę na Sympozjum Forum Młodych PTD w Łodzi (2011).

W okresie sprawozdawczym zorganizowano kursy: Katedra i Klinika Dermatologii w Katowicach 8 (4 - wprowadzenie do dermatologii, 3 - choroby zawodowe i orzecznictwo w dermatologii, 1 - choroby nowotworowe skóry), Katedra i Oddział Kliniczny Chorób Wewnętrznych i Dermatologii w Zabrzu 2 (choroby skóry - dermatologia dla alergologów).

5 lutego 2014 r. odbyło się Walne Zebranie Oddziału, po którym ukonstytuował się nowy zarząd i komisja rewizyjna w składzie: przewodnicząca zarządu - prof. zw. dr hab. med. Ligia Brzezińska-Wcisło, zastępca przewodniczącej - dr med. Mariola Wyględowska-Kania, sekretarz - dr med. Iwona Rogala-Poborska, skarbnik - dr med. Dominika Wcisło-Dziadecka, członkowie - dr med. Barbara Szpyrka, lek. Dorota Sobel, lek. Anna Ziajka-Paluch, komisja rewizyjna - dr med. Barbara Filipowska, lek. Barbara Seredyńska, lek. Radosław Truś.

Jednocześnie informuję, że zwyczajowo nasz oddział nazwano "Śląski”, natomiast w dokumentach rejestracyjnych (KRS) widnieje on jako Oddział Katowicki.

Sekretarz Oddziału Katowickiego Polskiego Towarzystwa Dermatologicznego dr med. Iwona Rogala-Poborska 